\title{
RESEARCH
}

Open Access

\section{Toxicity of tobacco Nicotiana tabacum Linnaeus (Solanaceae) leaf extracts to the rice weevil Sitophilus oryzae Linnaeus 1763 (Coleoptera: Curculionidae)}

Sekar Kanmani ${ }^{1}$, Lokesh Kumar ${ }^{2}$, Rajasingh Raveen ${ }^{2}$, Samuel Tennyson ${ }^{2 *}$ (D), Subramanian Arivoli ${ }^{3}$ and Manickkam Jayakumar ${ }^{4}$

\begin{abstract}
Background: Rice is the agricultural commodity with the third highest worldwide production and losses in rice storage due to insect pests may drastically affect the food availability for a large number of people. One of its serious pests in tropics is the "rice weevil", Sitophilus oryzae. Although few effective fumigants are available, there is a global concern about environmental pollution, toxicity to non-target organisms, and pesticide residues. Botanicals are a promising source of pest control compounds as the pool of plants possessing insecticidal substances are enormous and have generated extraordinary interest in recent years as potential sources of natural insect control agents. The present study was conducted to determine the toxicity of tobacco (Nicotiana tabacum) leaf extracts as an alternative to synthetic insecticides in the management of rice weevils. The crude solvent leaf extracts of $N$. tabacum were analyzed for its phytochemical compounds via GC-MS and tested for its toxicity to the adults of $S$. oryzae at concentrations of $0.625,1.25,2.50,5.00,10.00$, and $20.00 \mathrm{mg} / \mathrm{L}$ by Petri dish bioassay method. Adult mortality was calculated 24,48 , and $72 \mathrm{~h}$ after exposure.

Results: The constituent compounds in the chloroform and acetone revealed 13 compounds represented by benzene carboxylic acid ester, alkaloids, and steroids. The major compounds found in GC-MS analysis are nicotine, nicotinonitrile, nornicotine, nicotinic acid, neonicotine, cotinine, indole, farnesol, sclareol, 9,12-octadecadienoic acid, squalene, palmitic acid, and 15-tetracosenoic acid methyl ester. Overall assessment indicates that the chloroform and acetone extracts of $N$. tabacum leaves exhibited the highest adulticidal activity against $S$. oryzae. Their $\mathrm{LD}_{50}$ values were $1.62,0.64$, and $0.48 ; 1.54,0.83$, and $0.48 \mathrm{mg} / \mathrm{L}$ after 24,48 , and $72 \mathrm{~h}$ of exposure respectively. In addition, the petroleum ether extract also indicated high adult mortality with $L D_{50}$ value of $0.53 \mathrm{mg} / \mathrm{L}$ only at $72 \mathrm{~h}$.

Conclusions: The present research has documented its first report for the management of rice weevil using tobacco leaf extracts, and therefore on the basis of the results of the present study, it is highly encouraging to note that the use of tobacco leaf extracts with its excellent insecticidal activity owing to the action of nicotine would be economically feasible to alleviate the rice weevil problem.
\end{abstract}

Keywords: Nicotiana tabacum, Leaf extracts, GC-MS, Phytocompounds, Sitophilus oryzae, Adulticidal

\footnotetext{
* Correspondence: samtennyson@gmail.com

${ }^{2}$ Department of Zoology, Madras Christian College, Chennai, Tamil Nadu 600 059, India

Full list of author information is available at the end of the article
}

\section{Springer Open}

(- The Author(s). 2021 Open Access This article is licensed under a Creative Commons Attribution 4.0 International License, which permits use, sharing, adaptation, distribution and reproduction in any medium or format, as long as you give appropriate credit to the original author(s) and the source, provide a link to the Creative Commons licence, and indicate if changes were made. The images or other third party material in this article are included in the article's Creative Commons licence, unless indicated otherwise in a credit line to the material. If material is not included in the article's Creative Commons licence and your intended use is not permitted by statutory regulation or exceeds the permitted use, you will need to obtain permission directly from the copyright holder. To view a copy of this licence, visit http://creativecommons.org/licenses/by/4.0/. 


\section{Background}

The post-harvest grain losses on global basis caused by insect damage vary from 10 to $40 \%$, and approximately one third of the global food production is destroyed annually by field and storage pests (Raja, Albert, Ignacimuthu, \& Dorn, 2001). Stored products infestation by insects, particularly in the developing countries, may amount to $5-10 \%$ in the temperate countries and 20$30 \%$ in the tropical zones (Dubey, Srivastava, \& Kumar, 2008). Stored product pest causes serious losses in weight and quality of a wide range of commodities including grains, peas, nuts, and dried fruits, which are human reserve foods. Rice is the agricultural commodity with the third highest worldwide production, after sugarcane and maize (Rani, 2017). Losses in rice storage due to insect pests may drastically affect the food availability for a large number of people.

Weevils are the commonest pest of stored grains infesting rice. One of the serious pests of stored commodities in tropics is the "rice weevil", Sitophilus oryzae L. (Coleoptera: Curculionidae) (Lucas \& Riudavets, 2002). Rice weevils originated in India and then spread to Europe and other parts of the world through grain trade, thereby enjoying worldwide distribution (Arthur, 2002) attacking economically important crops (Shaaya, Ravid, Pasteer, Juven, \& Zisman, 1991). Rice weevils are perfectly able to infest grain kernel which is possible for most storage pests and because of this ability, they are classified as of primary colonizers (Fang, Subramanyam, \& Arthur, 2002). Adult weevils are brown in color meanwhile the immatures have creamy body with white and black head (Ziaee, Moharramipour, \& Francikowski, 2014). This pest being an internal feeder, and females oviposit on damaged grain or whole grain by making cavity through its snout; emerging larva damage the kernels by making feeding galleries and pupate inside aggregated grains. Newly emerged adults may spend several days within the grain before emerging through exit holes (Benhalima, Chaudhry, Mills, \& Price, 2004). The dead insects, larval exuviae, the products of metabolism in the infested grains not only decreases its nutritional and esthetic value but also reduces germination capacity and ends up with low quality of seeds (Moino, Alves, \& Pereira, 1998).

Attempts have been made to get complete control of the stored grain insects by insecticidal application but in vain (Metcalf, 1982). Although few effective fumigants are available, there is a global concern about environmental pollution, toxicity to non-target organisms, and pesticide residues. Moreover, S. oryzae has been reported to develop resistance to synthetic insecticides (Benhalima et al., 2004; Bughio \& Wilkins, 2004). Thus, there is an urgent need to find resources that effectively protect stored products alternative to synthetics which are environmentally safe. Botanicals are a promising source of pest control compounds as the pool of plants possessing insecticidal substances are enormous and have generated extraordinary interest in recent years as potential sources of natural insect control agents (FAO, 1992). Earlier, the present authors have experimented the plant extracts for the control of the sweet potato weevil, Cylas formicarius (Lokesh et al., 2017; Raveen et al., 2019a, 2019b). Further, the present authors have also reported the repellent activity and fumigant toxicity of plant oils on this rice weevil (Jayakumar, Arivoli, Raveen, \& Samuel, 2017). Consequently, the present research has documented its first report for the management of rice weevil using tobacco leaf extracts, and therefore this study was conducted to determine the toxicity of tobacco (Nicotiana tabacum) leaf extracts as an alternative to synthetic insecticides in the management of rice weevils.

\section{Methods}

\section{Plant collection and preparation of phytoextracts}

Mature and healthy leaves of $N$. tabacum were collected from Chennai, Tamil Nadu, India. Taxonomical identity of the plant was confirmed by Dr. D. Narasimhan, Associate Professor and Plant Taxonomist at Department of Plant Biology and Plant Biotechnology, Madras Christian College, Chennai, India. The leaves were then brought to the laboratory, washed in dechlorinated water, shade dried, and powdered with the aid of an electric blender. The powdered leaves $(1 \mathrm{~kg})$ were extracted with different solvents (3 L) each viz., hexane, petroleum ether, dichloromethane, chloroform, ethyl acetate, acetone, methanol, and distilled water in a Soxhlet apparatus (Vogel, 1978). The crude solvent leaf extracts thus obtained were then stored in air tight amber-colored bottles at $4{ }^{\circ} \mathrm{C}$. The extracting yields was estimated and subjected to the phytochemical evaluation and bioassay.

\section{Phytochemical screening}

The phytochemical evaluation of hexane, petroleum ether, dichloromethane, chloroform, ethyl acetate, acetone, methanol, and aqueous leaf extracts of $N$. tabacum was performed to identify the plant chemicals (Harborne, 1998). The major phytochemical constituents, viz., alkaloids (Humayun, Ibrar, \& Barkatullah, 2012), carbohydrates (Ajiboye, Ibukun, Edobor, Ojo, \& Onikanni, 2013), glycosides (Jaradat, Hussen, \& Ali, 2015), phenolics (Raaman, 2006), and steroids (Bargah, 2015), Karthishwaran, Mirunalini, Dhamodharan, Krishnaveni, and Arulmozhi (2010) for tannins, Ajiboye et al. (2013) for terpenoids, Djaafar and Ridha (2014) for saponins, Sheel, Nisha, and Kumar (2014) for flavonoids, and Firdouse and Alam (2011) for quinones were qualitatively determined. 


\section{Gas chromatography-mass spectrometry analysis}

This analysis was carried out for the promising leaf extract(s) of N. tabacum in the Sophisticated Instrumentation Facility, Chemistry Division, School of Advanced Science, VIT University, Vellore, Tamil Nadu, India. The Clarus $680 \mathrm{GC}$ used in the analysis employed a fused silica column, packed with Elite-5MS (5\% biphenyl 95\% dimethylpolysiloxane, $30 \mathrm{~m} \times 0.25 \mathrm{~mm}$ ID $\times 250 \mu \mathrm{m} \mathrm{df}$ ) and the components were separated using helium as carrier gas at a constant flow of $1 \mathrm{~mL} / \mathrm{min}$. The injector temperature was set at $260{ }^{\circ} \mathrm{C}$ during the chromatographic run. The extract sample $(1 \mu \mathrm{L})$ injected into the instrument with the oven temperature was as follows: 60 ${ }^{\circ} \mathrm{C}$ (2 min); followed by $300{ }^{\circ} \mathrm{C}$ at the rate of $10{ }^{\circ} \mathrm{C}$ $\min ^{-1}$; and $300{ }^{\circ} \mathrm{C}$, where it was held for $6 \mathrm{~min}$. The mass detector conditions were transfer line temperature $240{ }^{\circ} \mathrm{C}$; ion source temperature $240{ }^{\circ} \mathrm{C}$; and ionization mode electron impact at $70 \mathrm{eV}$, a scan time $0.2 \mathrm{~s}$, and a scan interval of $0.1 \mathrm{~s}$. The fragments were from 40 to $600 \mathrm{Da}$. The spectrums of the components were compared with the database of spectrum of known components stored in the gas chromatography-mass spectrometry-National Institute for Standards and Technology library.

\section{Culture of S. oryzae}

Parent stock of S. oryzae was obtained from infested raw rice grains from the local market, Chennai, Tamil Nadu, India. In the laboratory, the adult rice weevils were maintained on uninfested rice grains. Adults were removed after emergence and placed in separate cylindrical glass jars $(29 \mathrm{~cm}$ depth and $25 \mathrm{~cm}$ diameter) covered with a fine muslin cloth on a daily basis. The adults were reared at $28 \pm 2{ }^{\circ} \mathrm{C}, 65-70 \%$ relative humidity under a photoperiod of $12 \mathrm{~h}$ light/ dark cycle provided with fresh rice grains (Jayakumar et al., 2017; Longstaff, 1981).

\section{Adulticidal bioassay}

Mason, Seal, and Jansson (1991) methodology of Petri dish bioassay was adopted with minor changes for the present study against the adults of S. oryzae. For the bioassay, the $F_{1}$ generation of the adults from the culture was used. Ten unsexed 1-week-old adults were placed inside glass Petri dishes $(9.5 \mathrm{~cm}$ diameter) whose lower dish inner surface was placed with a Whatman No. 1 filter paper treated with different concentrations of the plant solvent extracts and thereafter the upper dish was closed. Prior to this, the solvent on the filter paper was allowed to evaporate completely at room temperature. Tests were carried at concentrations of $0.625,1.25,2.50$, $5.00,10.00$, and $20.00 \mathrm{mg} / \mathrm{L}$. Petri dishes containing the treated adults were then placed on a laboratory bench in the rearing room and mortality was determined 24,48 , and $72 \mathrm{~h}$ after exposure. Moribund individuals were scored dead if they showed no signs of movement. Tween 80 treated filter paper was used as treated control and the filter paper which received neither plant extract nor Tween 80 but distilled water served as untreated control. A total of three trials with three replicates per trial were carried out.

\section{Statistical analysis}

The percent adult mortality was calculated using the formula (1) and when there was mortality in control (520\%), it was corrected using Abbott's (1925) formula (2). Statistical analysis of all mortality data of adulticidal activity was subjected to probit analysis. One-way analysis of variance and Tukey's honestly significant difference post hoc tests were used to determine (i) if the mortality in treated bioassays significantly differed from that of the controls and at which doses in particular; and (ii) if there were significant differences in response between solvents of the extract group. For the latter, analysis excluded control mortalities from the data. The differences were considered as significant at $P \leq 0.05$ level. All statistics were conducted in IBM SPSS Statistics v22 with significance set at $95 \%$ confidence (SPSS, 2010).

Percent adult mortality (1):

$$
\frac{\text { Number of dead adults }}{\text { Number of adults introduced }} \times 100
$$

Corrected percentage of control mortality (2):

$$
\frac{1-n \text { in } T \text { after treatment }}{n \text { in } C \text { after treatment }} \times 100
$$

Where $n$ is the number of adults, $T$ is the treated, and $C$ is the control.

\section{Results}

The yields of different solvent extracts in the order of polarity reported elsewhere are $3.66,3.85,9.88,6.33$, $2.08,8.48,12.40$, and $11.36 \% \mathrm{w} / \mathrm{w}$. The phytochemical components of $N$. tabacum leaves extracted by different solvents were analyzed and identified as multiple chemical components. The extracts of tobacco leaves tested positive for alkaloids, cardiac glycosides, flavonoids, phenolic compounds, quinones, saponins, steroids, tannins, and terpenoids (Table 1). The constituent compounds in the chloroform and acetone revealed 13 compounds represented by benzene carboxylic acid ester, alkaloids, and steroids. The major compounds found in GC-MS analysis are nicotine, nicotinonitrile, nornicotine, nicotinic acid, neonicotine, cotinine, indole, farnesol, sclareol, 9,12-octadecadienoic acid, squalene, palmitic acid, and 15-tetracosenoic acid methyl ester (Table 2). The crude solvent leaf extracts of N. tabacum 
Table 1 Phytochemical analysis of Nicotiana tabacum leaf extracts

\begin{tabular}{|c|c|c|c|c|c|c|c|c|c|c|}
\hline \multirow[t]{2}{*}{ Solvents } & \multicolumn{10}{|c|}{ Phytochemicals ('+' indicates presence; ' - ' indicates absence) } \\
\hline & Alkaloids & Carbohydrates & Flavonoids & Glycosides & Phenolics & Quinones & Saponins & Steroids & Tannins & Terpenoids \\
\hline Hexane & - & - & - & - & - & - & + & + & - & + \\
\hline Petroleum ether & - & - & - & - & - & - & + & + & - & + \\
\hline Dichloromethane & + & - & - & - & - & - & - & - & - & + \\
\hline Chloroform & + & + & - & + & - & + & - & + & - & + \\
\hline Acetone & + & - & + & - & + & + & + & + & - & + \\
\hline Ethyl acetate & - & - & - & - & - & + & + & - & + & + \\
\hline Methanol & + & + & + & + & + & + & + & + & + & + \\
\hline Aqueous & + & + & + & + & - & - & - & + & + & - \\
\hline
\end{tabular}

showed adulticidal activity against $S$. oryzae. No adult mortality was observed in treated and untreated control. After $24 \mathrm{~h}$ of exposure, $100 \%$ adult mortality was observed in chloroform extract at $5.00 \mathrm{mg} / \mathrm{L}$ and in hexane, petroleum ether, ethyl acetate, and acetone extracts at $10.00 \mathrm{mg} / \mathrm{L}$ (Table 3; Fig. 1). The highest percent adult mortality at the lowest concentration was revealed by the crude chloroform extract with $\mathrm{LD}_{50}$ and $\mathrm{LD}_{90}$ values of 1.62 and $2.85 \mathrm{mg} / \mathrm{L}$, respectively (Table 6). The same trend followed after 48 and $72 \mathrm{~h}$ of exposure, except for $100 \%$ adult mortality at 2.5 and $1.25 \mathrm{mg} / \mathrm{L}$ in the chloroform extract, respectively (Tables 4 and 5; Figs. 2 and 3), and its $\mathrm{LD}_{50}$ and $\mathrm{LD}_{90}$ values were 0.64 and $0.99 ; 0.48$ and $0.80 \mathrm{mg} / \mathrm{L}$, respectively (Table 6). Overall assessment indicated the chloroform and acetone extracts at 24,48 , and $72 \mathrm{~h}$ and petroleum ether extract of $N$. tabacum leaves at $72 \mathrm{~h}$ only exhibited the highest adulticidal activity against $S$. oryzae.

\section{Discussion}

Insecticides are heavily used to control insects by killing them or preventing them from eating in undesirable behaviors (Afzal, Shad, Abbas, Ayyaz, \& Walker, 2015) but its application has proven to cause negative impacts on the environment, non-target organisms, and people's health, which has stimulated the search for alternative ways of controlling pests (Hamza, El-Orabi, Gharieb, ElSaeady, \& Hussein, 2016). The natural products of plants come as an alternative, ecologically more compatible in substitution to the synthetic insecticides. The use of plant material or crude plant extracts and essential oil as botanical insecticides for the protection of agriculture plants and related stored products from insect pests is as old as agriculture itself (El-Wakeil, 2013). Although there are many reports regarding insecticidal properties of plant extracts, the practical application of them is still limited (Hassan \& Gökçe, 2014). Botanical pesticides are known to be secondary metabolites that are produced in the plants as defense mechanism against herbivore predators (Gonzalez-Coloma, Reina, Diaz, Fraga, \& Santana-
Meridas, 2013) and produce a large variety of secondary metabolites which has wide range of activity including pesticide activity (Balasubramanian \& Tyagi, 2017; Samuel, Muthukumaran, Gurusubramanian, \& Senthilkumar, 2014). Most of the plant secondary metabolites belong to alkanes, alkenes, alkynes and simple aromatics, lactones, essential oils and fatty acids, terpenes, alkaloids, steroids, isoflavonoids, pterocarpans, and lignans (ElWakeil, 2013; Moshi \& Matoju, 2017). Law-Ogbomo (2007) reported that plant treatments of grains have no effect on seed viability and further stated that, such plant products could reduce the infestation of stored grain pests without causing any deleterious effect on grain quality.

Phytocompounds are known for insecticidal and pesticidal properties (Azmathullah, Sheriff, \& Mohideen, 2011). Literature indicate the importance of plants in the protection of grains by the way of direct mixing of dried leaves, plant powders, solvent extracts, and essential oils on grains during post-harvest storage (Rajapakse 2006) due to the bioactive compounds present in them. Many plants with identified active compounds are present but there are some limitations inherent to botanical pesticide success. The major problem is many researches have been stopped after identifying the insecticidal activity of extracts. Nonetheless, in the present investigation, the chemical examination of the $N$. tabacum leaf extracts displayed active phytocompounds responsible for the mortality of weevils. The results of the present study revealed that the chloroform and acetonic extracts of tobacco leaves exhibited more pronounced activity than the others. It was found that both these extracts being mid polar have presence of alkaloids, steroids, terpenoids, cardiac glycosides, and quinones. The performance of an extract used could have been due to concentrations of active compounds in the extract since it has been found that active principles in tobacco leaves readily dissolve in mid- and high-polar solvents than those of less polarity (Denloye, 2010) which was corroborated to the present study. Since the solvent blend used 
Table 2 Phytochemical compounds in the chloroform and acetone leaf extract of Nicotiana tabacum

\section{Compound \\ name}

Nicotine

Nornicotine

Nicotinic acid

13.73

Neonicotine

12.67

12.37

15.93

\section{Retention}

time (in min)

148.20

$\mathrm{C}_{9} \mathrm{H}_{12} \mathrm{~N}_{2}$

123.11

$\mathrm{C}_{6} \mathrm{H}_{5} \mathrm{NO}_{2}$

$\mathrm{C}_{6} \mathrm{H}_{4} \mathrm{~N}_{2}$<smiles>N#[Tl]</smiles>

C.

104.11$$
\mathrm{C}_{12} \mathrm{H}_{2}
$$<smiles>c1cncc(C2CCCN2)c1</smiles><smiles>CN1C=CC[C@H]1c1cccnc1</smiles><smiles>Cc1cccnc1</smiles><smiles>O=C(O)c1cccnc1</smiles><smiles>c1cncc(C2CCCCN2)c1</smiles> 
Table 2 Phytochemical compounds in the chloroform and acetone leaf extract of Nicotiana tabacum (Continued)

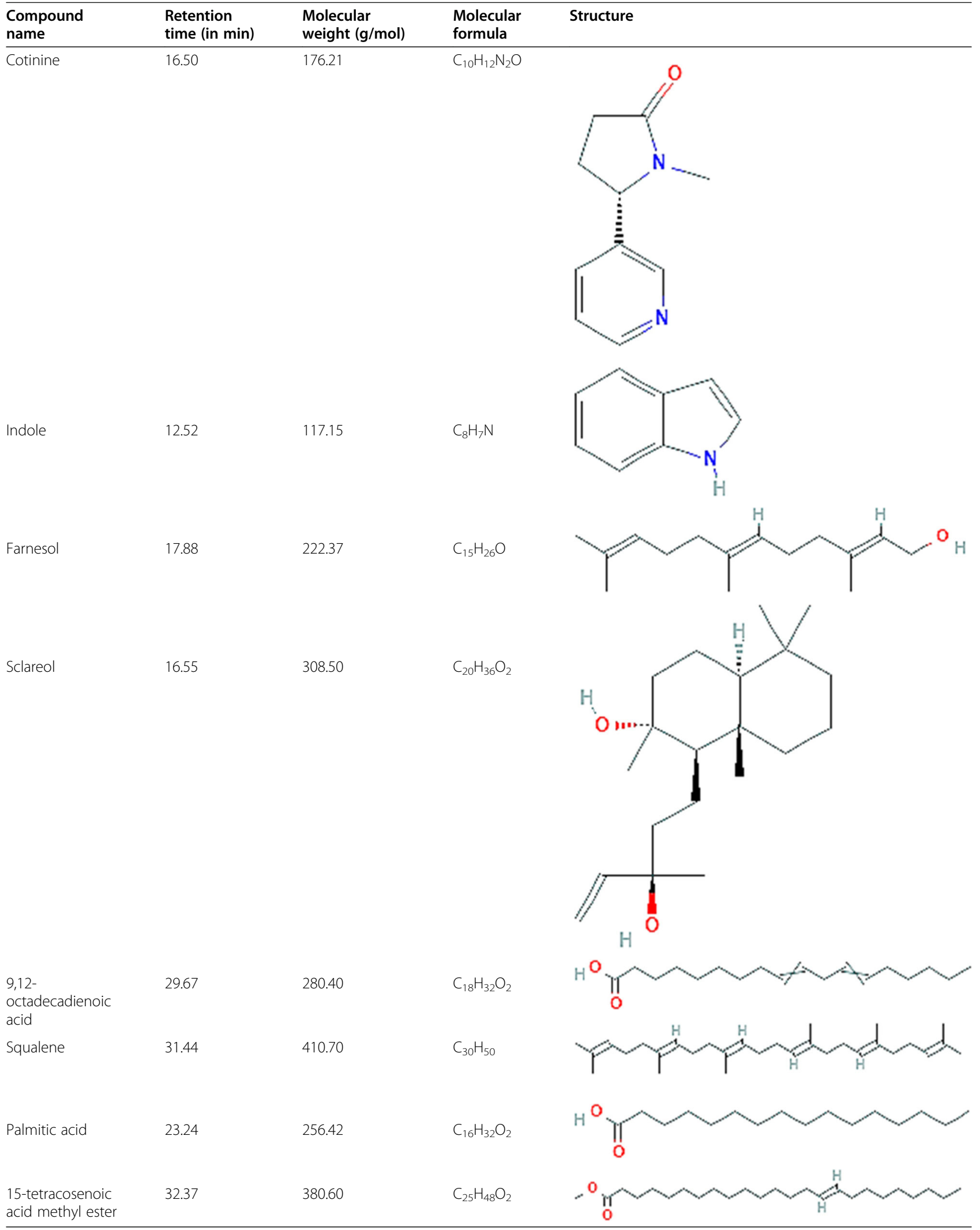


Table 3 Adulticidal activity of Nicotiana tabacum leaf extracts against Sitophilus oryzae at $24 \mathrm{~h}$

\begin{tabular}{|c|c|c|c|c|c|c|c|c|}
\hline \multirow[t]{2}{*}{ Solvent extracts } & \multicolumn{8}{|c|}{ Concentration (mg/L) } \\
\hline & UC & $\mathrm{TC}$ & 0.625 & 1.25 & 2.50 & 5.00 & 10.00 & 20.00 \\
\hline Hexane & $0.00 \pm 0.00^{\mathrm{a} 1}$ & $0.00 \pm 0.00^{\mathrm{a} 1}$ & $0.00 \pm 0.00^{\mathrm{at}}$ & $0.00 \pm 0.00^{\mathrm{a} 12}$ & $4.66 \pm 0.57^{\mathrm{b} 12}$ & $8.00 \pm 2.00^{c 2}$ & $10.0 \pm 0.00^{\mathrm{d} 2}$ & $10.0 \pm 0.00^{\mathrm{d} 2}$ \\
\hline Petroleum ether & $0.00 \pm 0.00^{\mathrm{a} 1}$ & $0.00 \pm 0.00^{\mathrm{a} 1}$ & $4.33 \pm 4.16^{\mathrm{ab} 12}$ & $8.00 \pm 1.00^{\mathrm{bc} 4}$ & $8.33 \pm 2.88^{b c 2}$ & $9.00 \pm 1.73^{\mathrm{bc} 2}$ & $10.0 \pm 0.00^{c 2}$ & $10.0 \pm 0.00^{c 2}$ \\
\hline Dichloromethane & $0.00 \pm 0.00^{\mathrm{a} 1}$ & $0.00 \pm 0.00^{\mathrm{a} 1}$ & $0.00 \pm 0.00^{\mathrm{a} 1}$ & $0.66 \pm 1.15^{\mathrm{ab} 12}$ & $0.66 \pm 0.57^{\mathrm{ab} 1}$ & $1.00 \pm 1.00^{\mathrm{ab} 1}$ & $4.00 \pm 3.00^{\mathrm{b} 1}$ & $4.33 \pm 2.08^{\mathrm{b} 1}$ \\
\hline Chloroform & $0.00 \pm 0.00^{\mathrm{a} 1}$ & $0.00 \pm 0.00^{\mathrm{a} 1}$ & $2.00 \pm 1.00^{\mathrm{b} 12}$ & $5.00 \pm 1.00^{c 3}$ & $7.33 \pm 0.57^{\mathrm{d} 2}$ & $10.0 \pm 0.00^{\mathrm{e} 2}$ & $10.0 \pm 0.00^{\mathrm{e} 2}$ & $10.0 \pm 0.00^{\mathrm{e} 2}$ \\
\hline Ethyl acetate & $0.00 \pm 0.00^{\mathrm{a} 1}$ & $0.00 \pm 0.00^{\mathrm{a} 1}$ & $0.00 \pm 0.00^{\mathrm{a} 1}$ & $0.00 \pm 0.00^{\mathrm{a} 1}$ & $3.00 \pm 2.64^{\mathrm{a} 1}$ & $9.33 \pm 1.15^{\mathrm{b} 2}$ & $10.0 \pm 0.00^{c 2}$ & $10.0 \pm 0.00^{c 2}$ \\
\hline Acetone & $0.00 \pm 0.00^{\mathrm{a} 1}$ & $0.00 \pm 0.00^{\mathrm{a} 1}$ & $5.66 \pm 0.57^{\mathrm{b} 2}$ & $7.00 \pm 1.00^{c 34}$ & $7.66 \pm 0.57^{\mathrm{cd} 2}$ & $8.66 \pm 0.57^{\mathrm{d} 2}$ & $10.0 \pm 0.00^{\mathrm{e} 2}$ & $10.0 \pm 0.00^{\mathrm{e} 2}$ \\
\hline Methanol & $0.00 \pm 0.00^{\mathrm{a} 1}$ & $0.00 \pm 0.00^{\mathrm{a} 1}$ & $1.00 \pm 1.00^{\mathrm{ab} 1}$ & $2.66 \pm 1.15^{b c}$ & $3.33 \pm 1.52^{\mathrm{bcc}}$ & $3.66 \pm 0.57^{c 1}$ & $5.00 \pm 1.00^{\mathrm{cd} 1}$ & $6.33 \pm 1.52^{\mathrm{d} 12}$ \\
\hline Aqueous & $0.00 \pm 0.00^{\mathrm{a} 1}$ & $0.00 \pm 0.00^{\mathrm{a} 1}$ & $0.00 \pm 0.00^{\mathrm{a} 1}$ & $0.33 \pm 0.57^{\mathrm{a} 1}$ & $0.66 \pm 0.57^{\mathrm{a} 1}$ & $3.66 \pm 0.57^{\mathrm{a} 1}$ & $4.00 \pm 2.64^{\mathrm{ab} 1}$ & $5.00 \pm 3.00^{\mathrm{b} 1}$ \\
\hline
\end{tabular}

Values are mean numbers expressed in $\mathrm{mg} / \mathrm{L}$. UC untreated control, TC treated control; values are mean of three replicates of three trials \pm standard deviation; different superscript alphabets in rows indicate values significant than respective UC and TC, and different superscript numerical in columns indicate values significant between the extracts difference at $p<0.05$ level by one-way ANOVA followed by Tukey test performed; similarity in superscript alphabets and numerical in rows and columns indicate no significant variation

for extraction had both polar and nonpolar components, the manifested activity of extract can therefore be attributed to fact that more active components were captured within the extract. These compounds affect the normal respiratory events in the insects (Adedire \& Ajayi, 1996), particularly in weevils (Yang, Zhu, \& Lei, 2012) and induce pain causing considerable stress to weevils leading to mortality (Nwachukwu \& Asawalam, 2014). All aforementioned factors were associated with the present study which involved the arrest of normal respiratory events within the weevils.

Reports regarding the toxicity of tobacco plant against pests of stored products (Baidoo \& Mochiah, 2016; Civelek \& Kaban, 2016; Idoko \& Adebayo, 2011;
Obembe \& Ogungbite, 2016; Sagheer et al., 2013; Suleiman \& Yusuf, 2011) and other species of Sitophilus (Danjumma et al., 2009; Longe, 2016; Onuminya, Agboola, \& Ezeribe, 2018) are documented, nevertheless exploring into its mode of action is wanting. Nenaah (2011) revealed the toxic effect of a certain kind of alkaloid known as glycoalkaloids from Solanum tuberosum and Lycopersicon esculentum against Tribolium castaneum and $S$. oryzae. This statement when compared to the present study threw light on an alkaloid nicotine present in tobacco leaf which was responsible for the weevil mortality. Nicotine is one of the oldest known plant origin insecticides, and an extremely fast-acting nerve toxin which possesses remarkable insecticidal

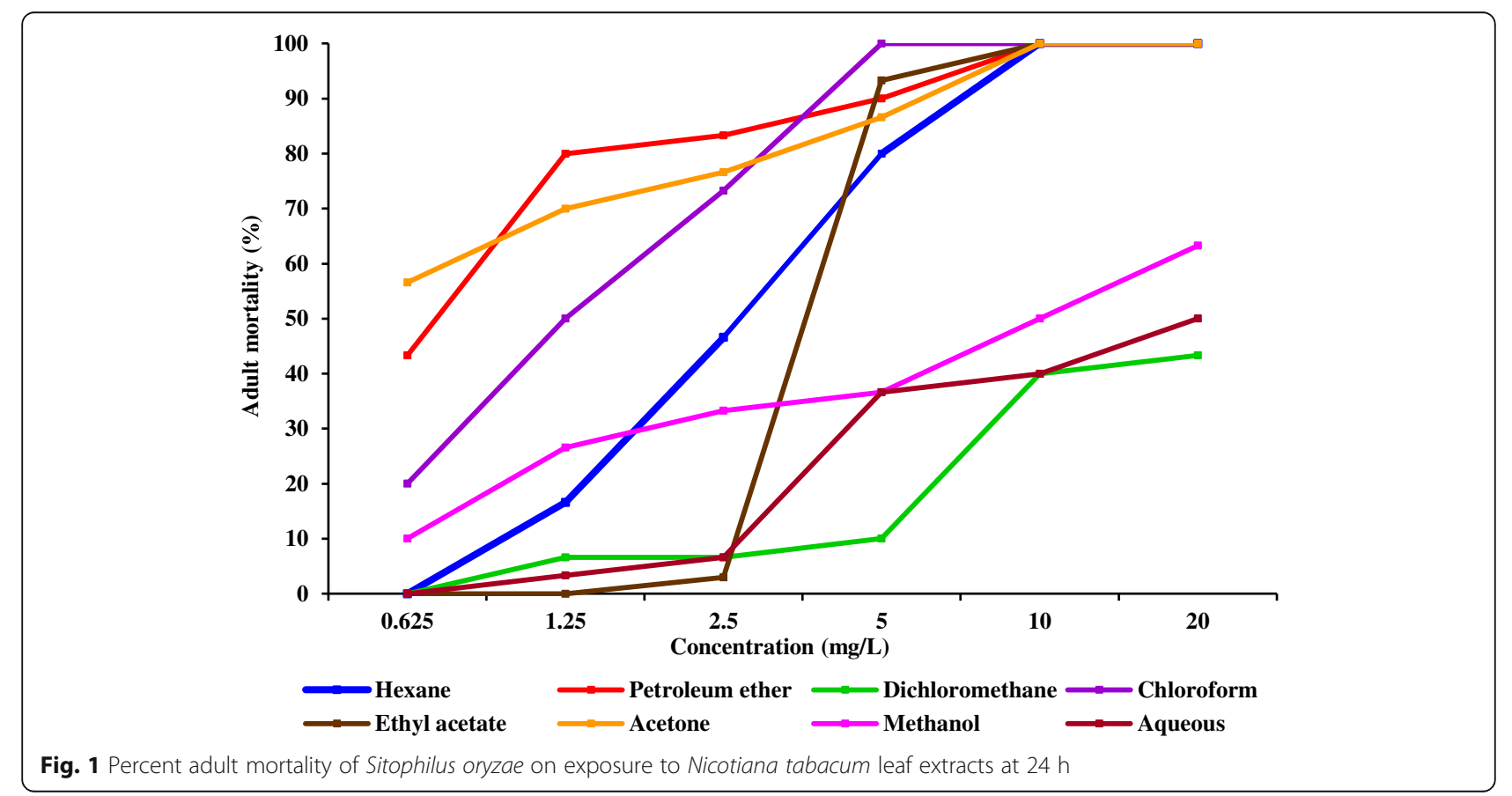


Table 4 Adulticidal activity of Nicotiana tabacum leaf extracts against Sitophilus oryzae at $48 \mathrm{~h}$

\begin{tabular}{|c|c|c|c|c|c|c|c|c|}
\hline \multirow[t]{2}{*}{ Solvent extracts } & \multicolumn{8}{|c|}{ Concentration (mg/L) } \\
\hline & UC & $\mathrm{TC}$ & 0.625 & 1.25 & 2.50 & 5.00 & 10.00 & 20.00 \\
\hline Hexane & $0.00 \pm 0.00^{\mathrm{a} 1}$ & $0.00 \pm 0.00^{\mathrm{a} 1}$ & $2.00 \pm 2.64^{\mathrm{a}}$ & $2.33 \pm 0.57^{\mathrm{a} 12}$ & $6.33 \pm 1.52^{\mathrm{b} 23}$ & $9.33 \pm 1.15^{c 23}$ & $10.0 \pm 0.00^{c 3}$ & $10.0 \pm 0.00^{c 2}$ \\
\hline Petroleum ether & $0.00 \pm 0.00^{\mathrm{a} 1}$ & $0.00 \pm 0.00^{\mathrm{a} 1}$ & $6.33 \pm 3.51^{\mathrm{b} 2}$ & $8.66 \pm 1.52^{\mathrm{b} 3}$ & $8.66 \pm 2.30^{\mathrm{b} 23}$ & $9.33 \pm 1.15^{\mathrm{b} 23}$ & $10.0 \pm 0.00^{\mathrm{b} 3}$ & $10.0 \pm 0.00^{\mathrm{b} 2}$ \\
\hline Dichloromethane & $0.00 \pm 0.00^{\mathrm{a} 1}$ & $0.00 \pm 0.00^{\mathrm{a} 1}$ & $0.00 \pm 0.00^{\mathrm{a} 12}$ & $1.00 \pm 1.73^{\mathrm{a} 1}$ & $1.33 \pm 1.15^{\mathrm{ab} 1}$ & $1.66 \pm 0.57^{\mathrm{abc} 1}$ & $5.00 \pm 2.64^{\mathrm{bc} 12}$ & $5.33 \pm 2.51^{c 1}$ \\
\hline Chloroform & $0.00 \pm 0.00^{\mathrm{a} 1}$ & $0.00 \pm 0.00^{\mathrm{a} 1}$ & $5.33 \pm 2.51^{\mathrm{b} 12}$ & $9.66 \pm 0.57^{c 3}$ & $10.00 \pm 0.00^{c 3}$ & $10.00 \pm 0.00^{c 3}$ & $10.00 \pm 0.00^{c 3}$ & $10.00 \pm 0.00^{c 2}$ \\
\hline Ethyl acetate & $0.00 \pm 0.00^{\mathrm{a} 1}$ & $0.00 \pm 0.00^{\mathrm{a} 1}$ & $0.66 \pm 0.57^{\mathrm{a} 1}$ & $1.00 \pm 0.00^{\mathrm{a} 1}$ & $5.00 \pm 3.60^{\mathrm{b} 12}$ & $9.66 \pm 0.57^{\mathrm{c3}}$ & $10.00 \pm 0.00^{c 3}$ & $10.00 \pm 0.00^{c 2}$ \\
\hline Acetone & $0.00 \pm 0.00^{\mathrm{a} 1}$ & $0.00 \pm 0.00^{\mathrm{a} 1}$ & $6.33 \pm 0.57^{\mathrm{b} 2}$ & $9.00 \pm 1.00^{c 3}$ & $9.00 \pm 1.00^{c 23}$ & $10.00 \pm 0.00^{c 3}$ & $10.00 \pm 0.00^{c 3}$ & $10.00 \pm 0.00^{c 2}$ \\
\hline Methanol & $0.00 \pm 0.00^{\mathrm{a} 1}$ & $0.00 \pm 0.00^{\mathrm{a} 1}$ & $3.00 \pm 2.00^{\mathrm{ab} 12}$ & $4.33 \pm 1.15^{\mathrm{bc} 2}$ & $5.00 \pm 1.73^{\mathrm{bcd} 12}$ & $6.33 \pm 3.05^{\mathrm{bcd} 2}$ & $8.33 \pm 1.15^{\mathrm{cd} 23}$ & $8.66 \pm 0.57^{\mathrm{d} 2}$ \\
\hline Aqueous & $0.00 \pm 0.00^{\mathrm{a} 1}$ & $0.00 \pm 0.00^{\mathrm{a} 1}$ & $0.33 \pm 0.57^{\mathrm{a} 1}$ & $0.66 \pm 0.57^{\mathrm{a} 1}$ & $1.00 \pm 0.00^{\mathrm{a} 1}$ & $4.00 \pm 0.57^{\mathrm{a} 1}$ & $4.66 \pm 3.05^{\mathrm{ab} 1}$ & $5.00 \pm 0.00^{\mathrm{b} 1}$ \\
\hline
\end{tabular}

Values are mean numbers expressed in $\mathrm{mg} / \mathrm{L}$. UC untreated control, TC treated control; values are mean of three replicates of three trials \pm standard deviation; different superscript alphabets in rows indicate values significant than respective UC and TC, and different superscript numerical in columns indicate values significant between the extracts difference at $p<0.05$ level by one-way ANOVA followed by Tukey test performed; similarity in superscript alphabets and numerical in rows and columns indicate no significant variation

activity. Nicotine kills the insects rapidly within an hour causing intensive tremors, convulsions, and then paralysis. It competes with acetylcholine, the major neurotransmitter, by bonding to acetylcholine receptors at nerve synapses and causing uncontrolled nerve firing. This disruption of normal nerve impulse activity results in rapid failure of those body systems that depend on nervous input for proper functioning (El-Wakeil, 2013). It has been proved that nicotine being an alkaloid, besides causing acute toxicity, leads to the disruption of biological membranes, malfunction of internal organs and metabolism, redox imbalance, and disturbances in the development and reproduction processes in insects or cause inhibition of food intake (Chowański et al., 2016). Further, nicotine reversibly inhibits the activity of acetylcholinesterase (AChE), an important enzyme that regulates synaptic transmission, and, thus, causes an imbalanced functioning of the nervous system. The excitation of the nervous system is one of the most important modes of action of conventional insecticides as organophosphates and carbamates. Inhibition of AChE was reported for crude extracts from plant families Asteraceae and Solanaceae to which tobacco is housed (Niño, Herńandez, Correa, \& Mosquera, 2006). This alkaloid acts by mimicking acetylcholine binding to acetylcholine receptors in the nervous system causing synaptic blocking and continuous firing of affected nerves which presents such symptoms as ganglionic stimulation which types into central nervous failure and death. This interruption in nervous system potentially leads to the death of the insect pest (Mohamed et al., 2017).

Interestingly, the insecticidal activity of alkaloids acts acutely by causing knockdown in beetles and weevils which drew the attention of researchers for its application in the management of coleopteran pests. According to Wickham, Chadwick, and Stewart (1974), knockdown is a state of intoxication and partial paralysis which usually precedes death in treated insects and the term 'knockdown' often is defined as the condition in which an insect lacks sufficient coordination to fly or walk.

Table 5 Adulticidal activity of Nicotiana tabacum leaf extracts against Sitophilus oryzae at $72 \mathrm{~h}$

\begin{tabular}{|c|c|c|c|c|c|c|c|c|}
\hline \multirow[t]{2}{*}{ Solvent extracts } & \multicolumn{8}{|c|}{ Concentration (mg/L) } \\
\hline & UC & $\mathrm{TC}$ & 0.625 & 1.25 & 2.50 & 5.00 & 10.00 & 20.00 \\
\hline Hexane & $0.00 \pm 0.00^{\mathrm{a} 1}$ & $0.00 \pm 0.00^{\mathrm{a} 1}$ & $3.66 \pm 2.08^{\mathrm{b} 12}$ & $4.00 \pm 1.73^{\mathrm{b} 2}$ & $6.66 \pm 2.08^{\mathrm{b} 2}$ & $9.66 \pm 0.57^{c 2}$ & $10.00 \pm 0.00^{c 2}$ & $10.00 \pm 0.00^{c 2}$ \\
\hline Petroleum ether & $0.00 \pm 0.00^{\mathrm{a} 1}$ & $0.00 \pm 0.00^{\mathrm{a} 1}$ & $7.00 \pm 3.00^{\mathrm{b} 23}$ & $10.00 \pm 0.00^{c 3}$ & $10.00 \pm 0.00^{c 2}$ & $10.00 \pm 0.00^{c 2}$ & $10.00 \pm 0.00^{c 2}$ & $10.00 \pm 0.00^{c 2}$ \\
\hline Dichloromethane & $0.00 \pm 0.00^{\mathrm{a} 1}$ & $0.00 \pm 0.00^{\mathrm{a} 1}$ & $0.33 \pm 0.57^{\mathrm{a} 1}$ & $1.33 \pm 1.52^{\mathrm{ab} 1}$ & $1.33 \pm 1.15^{\mathrm{ab} 1}$ & $2.33 \pm 0.57^{\mathrm{abcl}}$ & $5.00 \pm 2.64^{\mathrm{bcc}}$ & $6.00 \pm 2.64^{c 1}$ \\
\hline Chloroform & $0.00 \pm 0.00^{a 1}$ & $0.00 \pm 0.00^{\mathrm{a} 1}$ & $8.00 \pm 2.00^{\mathrm{b} 23}$ & $10.00 \pm 0.00^{c 3}$ & $10.00 \pm 0.00^{c 2}$ & $10.00 \pm 0.00^{c 2}$ & $10.00 \pm 0.00^{c 2}$ & $10.00 \pm 0.00^{c 2}$ \\
\hline Ethyl acetate & $0.00 \pm 0.00^{\mathrm{a} 1}$ & $0.00 \pm 0.00^{\mathrm{a} 1}$ & $0.66 \pm 0.57^{\mathrm{a} 1}$ & $1.00 \pm 0.00^{\mathrm{a} 1}$ & $6.00 \pm 3.60^{\mathrm{b} 2}$ & $10.00 \pm 0.00^{c 2}$ & $10.00 \pm 0.00^{c 2}$ & $10.00 \pm 0.00^{c 2}$ \\
\hline Acetone & $0.00 \pm 0.00^{\mathrm{a} 1}$ & $0.00 \pm 0.00^{\mathrm{a} 1}$ & $8.66 \pm 0.57^{b}$ & $9.66 \pm 0.57^{c 3}$ & $10.00 \pm 0.00^{c 2}$ & $10.00 \pm 0.00^{c 2}$ & $10.00 \pm 0.00^{c 2}$ & $10.00 \pm 0.00^{c 2}$ \\
\hline Methanol & $0.00 \pm 0.00^{\mathrm{a} 1}$ & $0.00 \pm 0.00^{\mathrm{a} 1}$ & $4.66 \pm 2.30^{\mathrm{b} 123}$ & $5.33 \pm 0.57^{\mathrm{bc2}}$ & $6.00 \pm 1.00^{\mathrm{bcd} 2}$ & $7.00 \pm 3.46^{\mathrm{bcd} 2}$ & $9.00 \pm 0.00^{\mathrm{cd} 2}$ & $9.66 \pm 0.57^{\mathrm{d} 2}$ \\
\hline Aqueous & $0.00 \pm 0.00^{\mathrm{a} 1}$ & $0.00 \pm 0.00^{\mathrm{a} 1}$ & $0.66 \pm 0.57^{\mathrm{a} 1}$ & $1.00 \pm 1.00^{\mathrm{a} 1}$ & $1.33 \pm 0.57^{\mathrm{a} 1}$ & $2.66 \pm 1.52^{\mathrm{ab} 1}$ & $4.66 \pm 3.05^{\mathrm{b} 1}$ & $5.00 \pm 0.00^{b 1}$ \\
\hline
\end{tabular}

Values are mean numbers expressed in $\mathrm{mg} / \mathrm{L}$. UC untreated control; TC treated control; values are mean of three replicates of three trials \pm standard deviation; different superscript alphabets in rows indicate values significant than respective UC and TC, and different superscript numerical in columns indicate values significant between the extracts difference at $p<0.05$ level by one-way ANOVA followed by Tukey test performed; similarity in superscript alphabets and numerical in rows and columns indicate no significant variation 


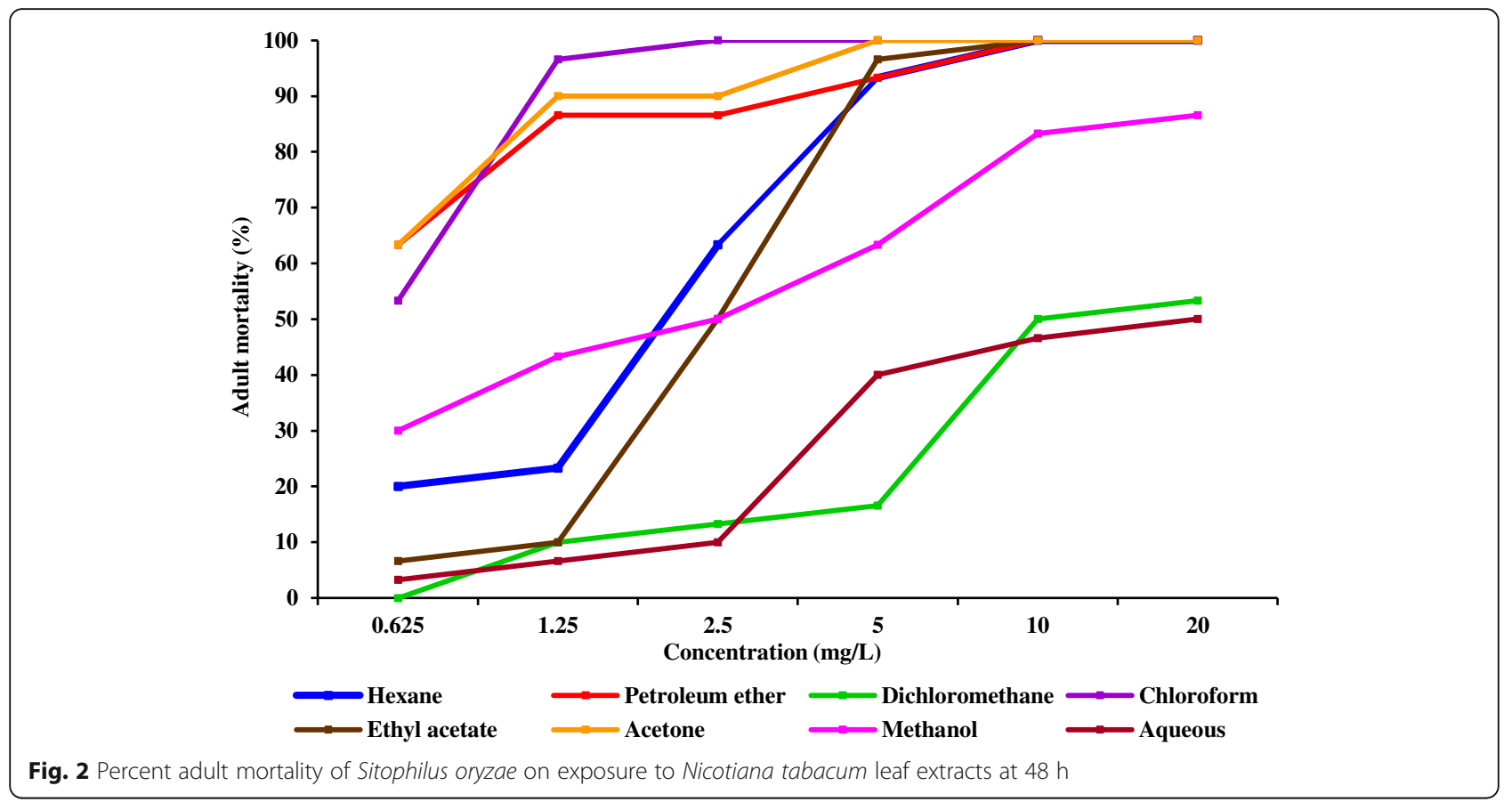

This principle will be interrogated in future as the present investigation has shown the activity of the alkaloid nicotine to cause mortality to weevils in addition to the sedative effect caused to weevils in the present study. Besides these, a few factors found to influence the biopesticide were (i) influence of exposure: the way in which insects pick up the dose of biopesticide gives rise to differences. This is related to whether the dose is given as a single initial application or there is continuous pick up over a period of time; (ii) distribution and size of biopesticide: particle size is a factor which may affect the amount picked up by insects by ensuring that an adequate volume reaches the insect. The rate of penetration of the biopesticide into the insect matters also; (iii) size of test chamber: the size of test chamber may also be of considerable importance. Contrary to expectation,

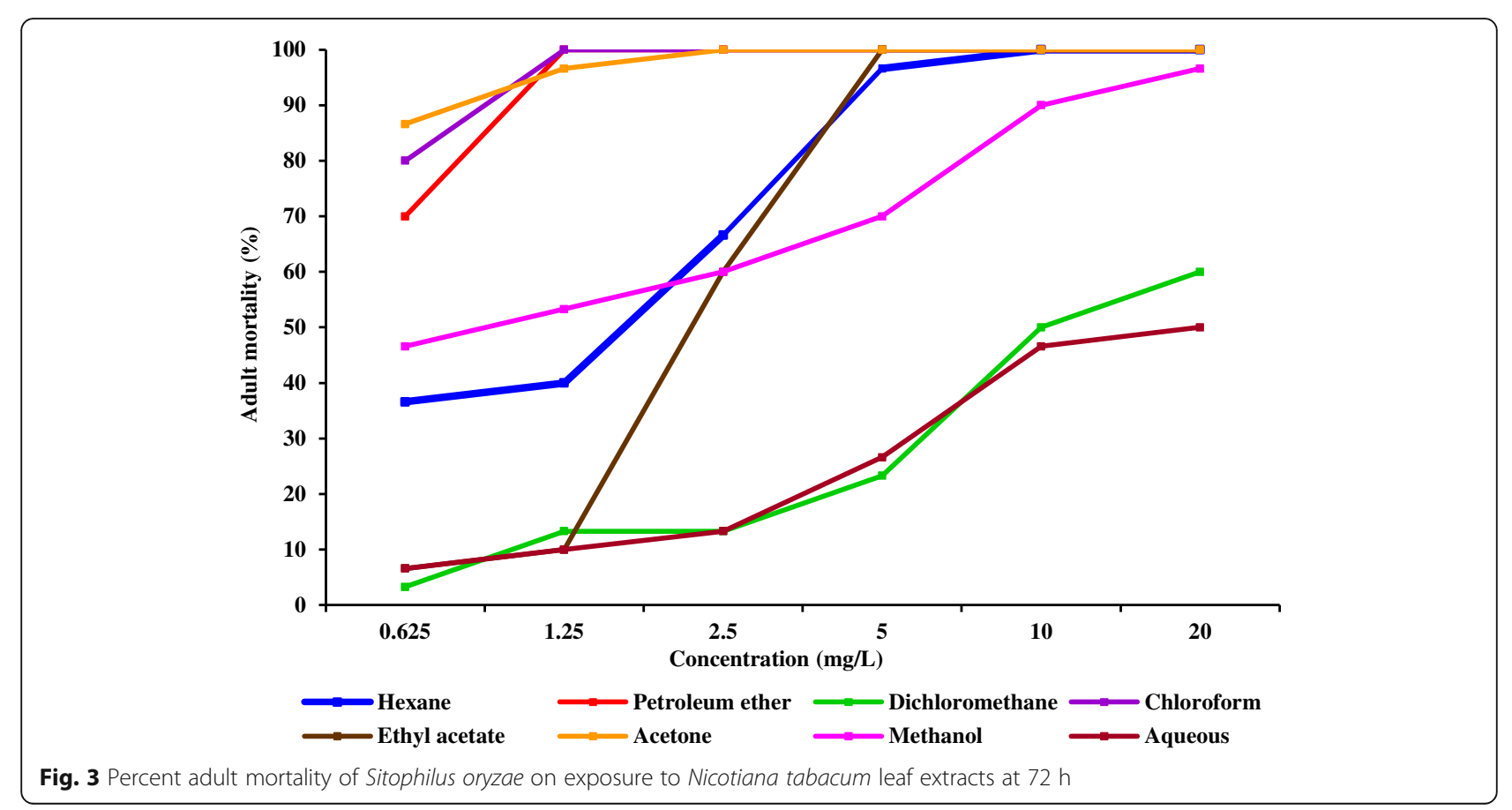


Table 6 Probit analysis of Nicotiana tabacum leaf extracts against the adults of Sitophilus oryzae

\begin{tabular}{|c|c|c|c|c|c|c|}
\hline \multirow[t]{4}{*}{ Solvent extracts } & \multicolumn{6}{|l|}{ Hours } \\
\hline & \multicolumn{2}{|l|}{24} & \multicolumn{2}{|l|}{48} & \multicolumn{2}{|l|}{72} \\
\hline & \multicolumn{6}{|c|}{ Concentration (mg/L) } \\
\hline & $\mathrm{LD}_{50}$ & $L^{2} D_{90}$ & $\mathrm{LD}_{50}$ & $\mathrm{LD}_{90}$ & $\mathrm{LD}_{50}$ & $\mathrm{LD}_{90}$ \\
\hline Hexane & $3.21(2.78-3.76)$ & $5.24(4.55-6.31)$ & $2.31(1.85-2.94)$ & $4.12(3.38-5.46)$ & $1.85(1.44-2.43)$ & $3.62(2.92-4.97)$ \\
\hline Petroleum ether & $1.41(0.38-2.84)$ & $3.45(2.29-8.56)$ & $1.07(-0.98-3.80)$ & $2.84(1.68-21.00)$ & $0.53(0.43-0.64)$ & $0.85(0.72-1.07)$ \\
\hline Dichloromethane & 18.76(14.59-27.55) & $32.04(24.46-50.22)$ & $15.85(12.24-22.91)$ & $28.55(21.87-43.97)$ & 14.53(11.37-20.18) & $27.04(21.08-39.64)$ \\
\hline Chloroform & $1.62(1.37-1.94)$ & $2.85(2.43-3.54)$ & $0.64(0.53-0.75)$ & $0.99(0.86-1.22)$ & $0.48(0.38-0.60)$ & $0.80(0.68-1.02)$ \\
\hline Ethyl acetate & $3.26(2.88-3.72)$ & $4.58(4.07-5.39)$ & $2.62(2.27-3.08)$ & $4.10(3.55-4.97)$ & $2.25(1.96-2.66)$ & $3.39(2.92-4.21)$ \\
\hline Acetone & $1.54(0.91-2.28)$ & $4.02(3.05-6.18)$ & $0.83(0.46-1.27)$ & $1.73(1.28-2.86)$ & $0.48(0.21-0.77)$ & $0.80(0.57-1.49)$ \\
\hline Methanol & $12.77(9.69-18.43)$ & $27.90(21.24-42.79)$ & $5.68(3.25-9.06)$ & $15.89(11.60-26.74)$ & $3.40(0.20-8.58)$ & $10.38(6.48-34.73)$ \\
\hline Aqueous & $17.36(14.05-23.20)$ & $29.29(23.39-41.22)$ & $9.63(8.27-11.52)$ & $15.66(13.37-19.22)$ & $9.11(7.76-11.00)$ & $15.64(13.30-19.40)$ \\
\hline
\end{tabular}

Values are expressed in $\mathrm{mg} / \mathrm{L}$. LD50 lethal concentration that kills $50 \%$ of the exposed adult, $L D 90$ lethal concentration that kills $90 \%$ of the exposed adult; values in parenthesis denotes $95 \%$ lower confidence limits-upper confidence limits

it was observed that the relationship between the size of test chamber and dosage rate may or may not be proportional; and (iv) effect of solvent: major changes in effect may be observed when using different solvents as carriers in insecticide products. All these above-pointed factors were observed in the present investigation. The evaluation of biopesticide must be relevant to practical conditions of use and although a laboratory technique may not entirely mimic the practical usage, it is essential that the means by which the biopesticide reaches the insect is basically the same. Without this, a valid assessment is difficult to achieve. Eventually, it is necessary to consider the effects of all the components together, since biopesticides providing mortality, synergists, and different solvents will all interact to give the final performance.

\section{Conclusion}

Even though the scientific literature documenting the efficacy of plant products to different insect pests continues to expand, so far only a handful of botanicals are being successfully used. On the basis of the results of the present study, it is highly encouraging to note that the use of tobacco leaf extracts with its excellent insecticidal activity would be economically feasible to alleviate the rice weevil problem. This is due to the fact that these products are highly promising, relatively available, cheap, and easy to prepare and apply on rice grains when compared to synthetic insecticides. Though the present contact toxicity bioassay exposed that the tobacco leaf extracts were moderate to strong toxicants to the adult weevils, it is to be noted that they were depended on the duration of exposure and concentration and route of application. The activity of plant-derived substances and plant extracts strongly depends on the solvent used by the researcher. The range and dynamic of the toxicity of extracts may double with the use of certain solvents.
Further, various stored grain pests may be differentially susceptible to active substances delivered in various solvents. Therefore, the need for a wide range of tests of biological activity of the substances in stored products protection is emphasized. A constituent's level study along with structure activity relationships of natural products is to be required for wider insecticidal performance and efficacy not only against $S$. oryzae but also against all other stored grain insect pests.

\section{Acknowledgements \\ Not applicable}

\section{Authors' contributions}

RR and ST planned the outline of the research work and supervised the work. SK and LK prepared the phytoextracts and performed the bioassay experiments. SA and MJ carried GC-MS analysis. ST wrote the manuscript and analyzed the data. RR, ST, SA, and MJ contributed in paper writing. All authors have read and approved the final manuscript.

\section{Funding}

Not applicable

\section{Availability of data and materials \\ The datasets used and/or analyzed during the current study are available from the corresponding author on reasonable request.}

\section{Ethics approval and consent to participate} Not applicable.

\section{Consent for publication}

Not applicable.

\section{Competing interests}

All authors declare that they have no competing interests.

\section{Author details}

'Department of Zoology, Pachaiyappa's College, Chennai, Tamil Nadu 600 030, India. ${ }^{2}$ Department of Zoology, Madras Christian College, Chennai, Tamil Nadu 600 059, India. ${ }^{3}$ Department of Zoology, Thiruvalluvar University, Vellore, Tamil Nadu 632 115, India. ${ }^{4}$ Department of Zoology, University of Madras, Chennai, Tamil Nadu 600 025, India. 
Received: 18 August 2020 Accepted: 6 January 2021

\section{Published online: 25 January 2021}

\section{References}

Abbott, W. S. (1925). A method of computing the effectiveness of an insecticide Journal of Economic Entomology, 18, 265-267.

Adedire, C. O., \& Ajayi, T. S. (1996). Assessment of insecticidal properties of some plants as grain protectants against the maize weevil, Sitophilus zeamais (Motsch.). Nigerian Journal of Entomology, 13, 93-101.

Afzal, M. B., Shad, S. A., Abbas, N., Ayyaz, M., \& Walker, W. B. (2015). Crossresistance, the stability of acetamiprid resistance and its effect on the biological parameters of cotton mealy bug, Phenacoccus solenopsis (Homoptera: Pseudococcidae), in Pakistan. Pest Management Science, 71, $151-158$.

Ajiboye, B. O., Ibukun, E. O., Edobor, G., Ojo, A. O., \& Onikanni, S. A. (2013). Qualitative and quantitative analysis of phytochemicals in Senecio biafrae leaf. International Journal of Pharmaceutical Science Invention, 1(5), 428-432.

Arthur, F. H. (2002). Survival of Sitophilus oryzae (L.) on wheat treated with diatomaceous earth: Impact of biological and environmental parameters on product efficacy. Journal of Stored Products Research, 38(3), 305-313.

Azmathullah, N., Sheriff, M. M. A., \& Mohideen, A. K. S. (2011). Phytochemical screening of Calotropis procera flower extracts and their biocontrol potential on Culex sp. mosquito larvae and pupae. International Journal of Pharmaceutical and Biological Archives, 2(6), 1718-1721.

Baidoo, P. K., \& Mochiah, M. B. (2016). Bioefficacy of garlic, Allium sativum and tobacco Nicotiana tabacum on mortality, ovipository inhibition and adult emergence of the cowpea beetle Callosobruchus maculatus (fab.) on cowpea Vigna unguiculata (L.) (Walp.). American Journal of Experimental Agriculture, 13(4), 1-9.

Balasubramanian, S., \& Tyagi, R. D. (2017). Biopesticide production from solid wastes. In Current Developments in Biotechnology and Bioengineering, (pp. 4358). New York: Elsevier.

Bargah, R. K. (2015). Preliminary test of phytochemical screening of crude ethanolic and aqueous extract of Moringa pterygosperma Gaertn. Journal of Pharmacognosy and Phytochemistry, 4(1), 07-09.

Benhalima, H., Chaudhry, M. Q., Mills, K. A., \& Price, N. R. (2004). Phosphine resistance in stored-product insects collected from various grain storage facilities in Morocco. Journal of Stored Products Research, 40, 241-249.

Bughio, F. M., \& Wilkins, R. M. (2004). Influence of malathion resistance status on survival and growth of Tribolium castaneum (Coleoptera: Tenebrionidae), when fed on flour from insect resistant and susceptible grain rice cultivars. Journal of Stored Products Research, 40, 65-75.

Chowański, S., Adamski, Z., Marciniak, P., Rosiński, G., Büyükgüzel, E., Büyükgüzel, K.,... Bufo, S. (2016). A review of bioinsecticidal activity of Solanaceae alkaloids. Toxins, 8, 1-28.

Civelek, H. S., \& Kaban, O. (2016). The effects of some natural substances on Acanthoscelides obtectus say (Coleoptera: Bruchidae). Agriculture and Food, 4, $537-543$.

Danjumma, B. J., Majeed, Q., Manga, S. B., Yabaya, A., Dike, M. C., \& Bamaiyi, L. (2009). Effect of some plants powders in the control of Sitophilus zeamais Motsch (Coleoptera: Curculionidae) infestation on maize grains. AmericanEurasian Journal of Scientific Research, 4(4), 313-316.

Denloye, A. A. (2010). Bioactivity of powder and extracts from garlic, Allium sativum L. (Alliaceae) and spring onion, Allium fistulosum L. (Alliaceae) against Callosobruchus maculatus F. (Coleoptera: Bruchidae) on cowpea, Vigna unguiculata (L.) Walp (Leguminosae) seeds. Entomology, 1, 1-5.

Djaafar, Z., \& Ridha, O. M. (2014). Phytochemical study of selected medicinal plant, Solanum nigrum, the Algerian desert. International Letters of Chemistry, Physics and Astronomy, 1, 25-30.

Dubey, N. K., Srivastava, B., \& Kumar, A. (2008). Current status of plant products as botanical insecticides in storage pest management. Journal of Biopesticides, 1(2), 182-186.

El-Wakeil, N. E. (2013). Botanical pesticides and their mode of action. Gesunde Pflanzen, 65(4), 125-149.

Fang, L., Subramanyam, B., \& Arthur, F. H. (2002). Effectiveness of spinosad on four classes of wheat against five stored-product insects. Journal of Economic Entomology, 95(3), 640-650.

FAO (1992). Pesticide residues in food: 1992, report of the Joint Meeting of the FAO Panel of Experts on Pesticide Residues in Food and the Environment and the WHO Expert Group on Pesticide Residues, Rome, 21-30 September 1992.
Firdouse, S., \& Alam, P. (2011). Phytochemical investigation of extract of Amorphophallus campanulatus tubers. International Journal of Phytomedicine, 3, 32-35.

Gonzalez-Coloma, A., Reina, M., Diaz, C. E., Fraga, B. M., \& Santana-Meridas, O. (2013). Natural product-based biopesticides for insect control Reference module in Chemistry, Molecular Sciences and Chemical Engineering, Elsevier.

Hamza, A. F., El-Orabi, M. N., Gharieb, O. H., El-Saeady, A. H. A., \& Hussein, A. R. E. (2016). Response of Sitophilus granarius $L$. to fumigant toxicity of some plant volatile oils. Journal of Radiation Research and Applied Science, 9, 3-14.

Harborne, J. (1998). Phytochemical methods: A guide to modern techniques of plant analysis. London: Kluwer Academic Publishers.

Hassan, E., \& Gökçe, A. (2014). Production and consumption of biopesticides. In S. Dwijendra (Ed.), Advances in plant biopesticides, (pp. 361-379). New Delhi: Springer.

Humayun, S., Ibrar, M., \& Barkatullah, A. I. (2012). Comparison of three extracts of Fumeria indica for the evaluation of cytotoxic and phytotoxic activities. International Journal of Biosciences, 2(12), 112-119.

Idoko, J. E., \& Adebayo, R. A. (2011). Efficacy of single and combined leaf powder of Nicotiana tabacum L. (Solanales: Solanaceae) with reduced rates of pirimiphos-methyl in management of Sitophilus zeamais Motschulsky (Coleoptera: Curculionidae). Journal of Agricultural Science, 3(1), 276-280.

Jaradat, N., Hussen, F., \& Ali, A. A. (2015). Preliminary phytochemical screening, quantitative estimation of total flavonoids, total phenols and antioxidant activity of Ephedra alata Decne. Journal of Materials and Environmental Science, 6(6), 1771-1778.

Jayakumar, M., Arivoli, S., Raveen, R., \& Samuel, T. (2017). Repellent activity and fumigant toxicity of a few plant oils against the adult rice weevil Sitophilus oryzae Linnaeus 1763 (Coleoptera: Curculionidae). Journal of Entomology and Zoology Studies, 5(2), 324-335.

Karthishwaran, K., Mirunalini, S., Dhamodharan, G., Krishnaveni, M., \& Arulmozhi, V. (2010). Phytochemical investigation of methanolic extract of the leaves of Pergularia daemia. Journal of Biological Sciences, 10(3), 242-246.

Law-Ogbomo, K. E. (2007). Reduction of post-harvest loss caused by Callosobruchus maculatus (F.) in three varieties of cow-pea treated with plant oils. Journal of Entomology, 4(3), 194-201.

Lokesh, K. V., Kanmani, S., Adline, J. D., Raveen, R., Samuel, T., Arivoli, S., \& Jayakumar, M. (2017). Adulticidal activity of Nicotiana tabacum Linnaeus (Solanaceae) leaf extracts against the sweet potato weevil Cylas formicarius Fabricius 1798 (Coleoptera: Brentidae). Journal of Entomology and Zoology Studies, 5(5), 518-524.

Longe, O. O. (2016). Insecticidal action of some plant powders on maize weevil (Sitophilus zeamais (Motschulsky) (Coleoptera: Curculionidae)) affecting stored maize grains (Zea mays). International Journal of Agriculture Innovations and Research, 4(4), 784-788.

Longstaff, B. C. (1981). Biology of the grain pest species of the genus Sitophilus (Coleoptera: Curculionidae): A critical review. Protection Ecology, 3, 83-130.

Lucas, E., \& Riudavets, J. (2002). Biological and mechanical control of Sitophilus oryzae (Coleoptera: Curculionidae) in rice. Journal of Stored Products Research, 38, 293-304.

Mason, L. J., Seal, D. R., \& Jansson, R. K. (1991). Response of sweet potato weevil (Coleoptera: Apionidae) to selected insecticides. Florida Entomologist, 74, 350-355.

Metcalf, R. L. (1982). Insecticides in pest management. In R. L. Metcalf, \& W. H. Luckman (Eds.), Introduction to insect Pest management, (2nd ed., pp. 235273). New York: Wiley.

Mohamed, M. A., Mahdy, E. S., Ghazy, A. E., Ibrahim, N. M., El-Mezayen, H. A. \& Ghanem, M. M. E. (2017). Acetylcholinesterases from entomopathogenic nematode Heterorhabditid bacteriophora: Susceptibility to insecticides and immunological characteristics. Pesticide Biochemistry and Physiology, 135, 27-34.

Moino, A. J., Alves, S. B., \& Pereira, R. M. (1998). Efficacy of Beauveria bassiana (Balsamo) Vuillemin isolates for control of stored-grain pests. Journal of Applied Entomology, 122, 301-305.

Moshi, A. P., \& Matoju, I. (2017). The status of research on and application of biopesticides in Tanzania. Review. Crop Protection, 92, 16-28.

Nenaah, G. (2011). Individual and synergistic toxicity of solanaceous glycoalkaloids. Journal of Pest Science, 84, 77-86.

Niño, J., Herńandez, J. A., Correa, Y. M., \& Mosquera, O. M. (2006). In vitro inhibition of acetylcholinesterase by crude plant extracts from Colombian flora. Memórias do Instituto Oswaldo Cruz, 101(7), 783-785.

Nwachukwu, I. D., \& Asawalam, E. F. (2014). Evaluation of freshly prepared juice from garlic (Allium sativum L.) as a bio-pesticide against the maize weevil, 
Sitophilus zeamais (Motsch.) (Coleoptera: Curculionidae). Journal of Plant Protection Research, 54, 132-138.

Obembe, O. M., \& Ogungbite, O. C. (2016). Entomotoxic effect of tobacco seed extracted with different solvents against Callosobruchus maculatus. International Journal of Entomology Research, 1(1), 22-26.

Onuminya, T. O., Agboola, O. O., \& Ezeribe, S. R. (2018). Insecticidal evaluation of some botanical powders as stored maize grain protectants against Sitophilus zeamais (Motschulsky) (Coleoptera: Curculionidae): A concern for postharvest loss. Annals of West University of Timişoara, ser. Biology, 21(2), 157-164.

Raaman, N. (2006). Phytochemical techniques. New Delhi: New India Publishing.

Raja, N., Albert, S., Ignacimuthu, S., \& Dorn, S. (2001). Effect of plant volatile oils in protecting stored cowpea Vigna unguiculata (L.) Walpers against Callosobruchus maculatus (F.) (Coleoptera: Bruchidae) infestation. Journal of Stored Products Research, 37, 127-132.

Rajapakse, R. H. S. (2006). The potential of plants and plant products in stored insect pest management. The Journal of Agricultural Sciences, 2(1), 11-21.

Rani, A. (2017). Bioefficacy of extract of turmeric and ginger as potential biopesticides on Sitophilus oryzae. Advanced Scientific Research, 2(1), 10-11.

Raveen, R., Kanmani, S., Lokesh, K. V., Samuel, T., Arivoli, S., \& Jayakumar, M. (2019a). Efficacy of Piper betle leaf extracts against sweet potato weevil Cylas formicarius (F.). Indian Journal of Entomology, 81(1), 201-205.

Raveen, R., Kanmani, S., Lokesh, K. V., Samuel, T., Arivoli, S., \& Jayakumar, M. (2019b). Toxicity of arecanut extracts to sweet potato weevil. Pestology, XLIII(3), 41-43.

Sagheer, M., Ali, K., Hasan, M., Rashid, A., Sagheer, U., \& Alvi, A. (2013). Repellent and toxicological impact of acetone extracts of Nicotiana tabacum, Pegnum hermala, Saussurea costus and Salsola baryosma against red flour beetle, Tribolium castaneum (Herbst). Pakistan Journal of Zoology, 45(6), 1735-1739.

Samuel, L., Muthukumaran, R. B., Gurusubramanian, G., \& Senthilkumar, N. (2014). Larvicidal activity of Ipomoea cairica (L.) Sweet and Ageratina adenophora (Spreng.) King \& H. Rob. plant extracts against arboviral and filarial vector, Culex quinquefasciatus say (Diptera: Culicidae). Experimental Parasitology, 141, $112-121$.

Shaaya, E., Ravid, U., Pasteer, N., Juven, B., \& Zisman, U. (1991). Insecticidal activity of essential oils against four major stored product insects. Journal of Chemical Ecology, 17(3), 499-504.

Sheel, R., Nisha, K., \& Kumar, J. (2014). Preliminary phytochemical screening of methanolic extract of Clerodendron infortunatum. IOSR Journal of Applied Chemistry, 7(1), 10-13.

SPSS (2010). IBM SPSS statistics for windows, version 22.0. Armonk: IBM Corp.

Suleiman, M., \& Yusuf, M. A. (2011). The potential of some plant powders as biopesticides against Sitophilus zeamais (Motsch.) (Coleoptera: Curculionidae) and Callosobruchus maculatus (F.) (Coleoptera: Bruchidae) on stored grains: A review. Bayero Journal of Pure and Applied Sciences, 4(2), 204-207.

Vogel, A. L. (1978). Text book of practical organic chemistry, (p. 1363). London: The English Language Book Society and Longman.

Wickham, J. C., Chadwick, P. R., \& Stewart, D. C. (1974). Factors which influence the knockdown effect of insecticide products. Pesticide Science, 5, 657-664.

Yang, F. L., Zhu, F., \& Lei, C. L. (2012). Insecticidal activities of garlic substances against adults of grain moth, Sitotroga cerealella (Lepidoptera: Gelechiidae). Insect Sci., 19, 205-212.

Ziaee, M., Moharramipour, S., \& Francikowski, J. (2014). The synergistic effects of Carum copticum essential oil on diatomaceous earth against Sitophilus granarius and Tribolium confusum. Journal of Asia-Pacific Entomology, 17(4), 817-822.

\section{Publisher's Note}

Springer Nature remains neutral with regard to jurisdictional claims in published maps and institutional affiliations.

\section{Submit your manuscript to a SpringerOpen ${ }^{\circ}$ journal and benefit from:}

- Convenient online submission

- Rigorous peer review

- Open access: articles freely available online

High visibility within the field

- Retaining the copyright to your article

Submit your next manuscript at $\boldsymbol{\nabla}$ springeropen.com 